\title{
EFEKTIVITAS PEMANFAATAN MEDIA ONLINE DALAM PEMBELAJARAN DI MASA PANDEMI COVID-19
}

\author{
Hasan Basri1", Lely Fathiyatus Sa'diyah1, Siti Nur Khasanah1, \\ Danial Hilmi ${ }^{1}$ \\ ${ }^{1}$ Pascasarjana UIN Maulana Malik Ibrahim Malang
}

\begin{abstract}
This research aims to determine what applications are used by lecturers and students in learning and how it's effectiveness in supporting the learning process. The approach used in this research is qualitative, with data collection through observation, documentation, and interviews. To test the validity of the data, triangulation of sources, data and discussions with peers was used. Data was collected by interview via WhatsApp to ten students of UIN Maulana Malik Ibrahim Malang. The result shows that lecturers and students using apps Zoom Meeting, Google Meet, E-learning and WhatsApp Group to support learning online. Lectures with these media often have problems with the signal or internet network, especially for students who live in areas with poor signal and do not use wifi and that will also have an impact on the quality of learning that students receive. However, this application media is still considered effective by the majority of students, because it has advantages in practicality, saves costs and time, and facilitates communication between lecturers and students.
\end{abstract}

Keywords: Social Media Application, Online Learning, Arabic Language Learning

*Korespondensi Penulis: hasanmasykur9@gmail.com 


\begin{abstract}
Abstrak: Penelitian ini bertujuan untuk mengetahui aplikasi apa saja yang digunakan oleh dosen dan mahasiswa pascasarjana jurusan PBA UIN Maulana Malik Ibrahim Malang dalam pembelajaran serta bagaimana keefektifannya dalam menunjang proses pembelajaran. Pendekatan yang digunakan dalam penelitian ini adalah kualitatif, dengan pengumpulan data melalui teknik observasi, dokumentasi, dan wawancara. Untuk menguji validitas data, digunakan triangulasi sumber, data dan diskusi dengan teman sejawat. Pengumpulan data dilakukan dengan wawancara melalui Whatsapp kepada 10 mahasiswa Prodi Pendidikan Bahasa Arab Pascasarjana UIN Maulana Malik Ibrahim Malang. Hasil penelitian menunjukkan bahwa dosen dan mahasiswa dalam menunjang pembelajaran secara online menggunakan aplikasi Zoom Meeting, Google Meet, E-learning dan Whastapp Group. Perkuliahan dengan media-media tersebut sering terjadi kendala terhadap signal atau jaringan internet, terutama bagi mahasiswa yang tinggal di daerah yang susah signal dan tidak menggunakan wifi dan yang nantinya akan berdampak pula kepada kualitas pembelajaran yang mahasiswa terima. Meski demikian, media aplikasi ini masih dinilai efektif oleh mayoritas mahasiswa, karena memiliki keunggulan dalam kepraktisan, menghemat biaya dan waktu, serta memudahkan komunikasi antara dosen dan mahasiswa.
\end{abstract}

\title{
Kata Kunci: Aplikasi Media sosial, Pembelajaran Online, Pendidikan Bahasa Arab.
}

\section{A. Pendahuluan}

Pandemi Covid-19 sejak ditemukan pertama kali di Wuhan, Hubei, China pada tahun 2019 telah merubah tatanan kehidupan masyarakat global, mulai dari kehidupan sosial mereka, ekonomi, politik, dan juga pendidikan. ${ }^{1}$ Diantara sektorsektor tersebut, organasi interanasional PBB menangkap bahwa pendidikan

1 Adib Rifqi Setiawan dan Arij Zulfi Mufassaroh, "Lembar Kegiatan Siswa untuk Pembelajaran Jarak Jauh Berdasarkan Literasi Saintifik pada Topik Penyakit Coronavirus 2019 (COVID-19)," Thesiscommons.org., 2020. 
menjadi salah satu sektor yang begitu berdampak oleh adanya virus ini. ${ }^{2}$ Maka dari itu, banyak negara di berbagai belahan dunia memutuskan untuk menutup instansi-instansi pendidikan mereka demi memutus mata rantai penyebaran Covid-19, termasuk dintaranya adalah Indonesia. ${ }^{3}$ Namun bukan berarti kegiatan belajar dan mengajar dihentikan, melainkan dialihkan secara online di rumah masing-masing. Hal ini tentu akan mengubah wajah baru dunia pendidikan di Indonesia, khususnya, dimana teknologi berbasis aplikasi memiliki peran yang sangat vital di dalamnya.

UIN Maulana Malik Ibrahim Malang selaku instansi pendidikan yang berada di bawah naungan kementrian agama juga turut mengaplikasikan metode pembelajaran online ini di dalam kegiatan belajar dan mengajar mereka. Lantas, seberapa efektivitas metode tersebut dalam pembelajaran, salah satunya pembelajaran mahasiwa para civitas akademika UIN Maulana Malik Ibrahim Malang? Dari latar belakang inilah peneliti berusaha untuk mengkaji peran media aplikasi ini dalam pembelajaran di tengah merebaknya pandemi Covid-19 di seluruh penjuru dunia.

Dari pengamatan yang telah peneliti lakukan, terdapat beberapa peneliti yang telah melakukan kajian ini, diantaranya adalah kajian yang telah dilakukan oleh Rahmat Iswanto yang berjudul "Pembelajaran Bahasa Arab Dengan Pemanfaatan Teknologi". Tulisan ini mengkaji tentang bagaimana teknologi dapat dimanfaatkan dalam proses pembelajaran bahasa Arab. Berbagai permasalahan pembelajaran bahasa Arab sesuai denga konteks yang dihadapi di berbagai lembaga pendidikan, tenaga pengajar memungkinkan melakukan modifikasi metode belajar mengajar. Hal ini dapat dilakukan dengan perkembangan teknologi yang memuat banyak informasi yang dapat digunakan untuk peningkatan hasil belajar. Penelitian ini menggunakan metode deskriptif kualitatif dengan hasil pembahasan bahwa penerapan teknologi dalam pembelajaran bahasa

2 Natasya Leuwol dan Sherly Gaspersz, "Perubahan Karakter Belajar Mahasiswa Di Tengah Pandemik Covid-19," Civic-Culture: Jurnal Ilmu Pendidikan PKN dan Sosial Budaya 4, no. 1 Extra (2020): hlm. 33.

${ }^{3}$ Rizqon Halal Syah Aji, "Dampak COVID-19 pada pendidikan di indonesia: Sekolah, keterampilan, dan proses pembelajaran," Salam: Jurnal Sosial dan Budaya Syar-i.(7) 5 (2020): hlm. 396. 
Arab akan menjadikan peserta didik semakin tertarik mempelajari bahasa Arab. Teknologi dapat menciptakan realisasi dan relevansi degan apa yang dirasakan peserta didik. Teknologi dapat menciptakan media-media pembelajaran bahasa Arab yang lebih bervariasi yang selama ini masih terasa kurang. 4

Penelitian yang setema juga pernah dilakukan oleh Asiefatul Fikriyah yang berjudul "Pemanfaatan Aplikasi Comic Page Creator Sebagai Strategi Untuk Menggali Keterampilan Menulis Dalam Bahasa Arab". Penelitian ini bertujuan untuk mendeskripsikan pemanfaatan aplikasi comic page creator dalam pembelajaran bahasa Arab sebagai media untuk berinovasi dan berkreasi. Dengan metode deskriptif kualitatif, penelitian ini menemukan hasil bahwa media aplikasi comic page creator dapat digunakan untuk mengasah keterampilan berbahasa siswa yaitu menulis. Pemanfaatan aplikasi dengan bimbingan dan arahan guru ini diharapkan mampu merangsang kemampuan siswa dalam menulis bahasa Arab. 5

Abdul Rozak dan Azkia Muaharom Albantani juga melakukan kajian dengan objek teknologi yang berjudul “Desain Perkuliahan Bahasa Arab Melalui Goggle Classroom”. Penelitian ini mengkaji tentang bentuk desain pembelajaran bahasa Arab dengan menggunakan media aplikasi google classroom. Jenis penelitian ini merupakan penelitian kualitiatif berbasis lapangan. Dalam hasilnya, penelitian ini menunjukkan bahwa aplikasi ini dapat membantu memudahkan dosen dan mahasiswa dalam melaksanakan proses belajar dengan lebih mendalam. Hal ini disebabkan karena baik mahasiswa maupun dosen dapat mengumpulkan tugas, mendistribusikan tugas, menilai tugas di rumah atau dimanapun tanpa terikat batas waktu atau jam pelajaran. ${ }^{6}$

Dari beberapa kajian di atas, ditemukan perbedaan antara kajian-kajian tersebut dengan penelitian ini, yaitu penelitian yang dilakukan oleh Rahmat Iswanto ini adalah

4 Rahmat Iswanto, "Pembelajaran Bahasa Arab Dengan Pemanfaatan Teknologi," Arabiyatuna: Jurnal Bahasa Arab 1, no. 2 (2017): 139-52.

${ }^{5}$ Asiefatul Fikriyyah, "Pemanfaatan Aplikasi 'Comic Page Creator' sebagai Strategi untuk Menggali Keterampilan Menulis dalam Bahasa Arab," Prosiding Konfererensi Nasional Bahasa Arab 3, no. 3 (2017): 282-88.

6 Abd Rozak dan Azkia Muharom Albantani, "Desain perkuliahan bahasa arab melalui google classroom," Arabiyat: Jurnal Pendidikan Bahasa Arab dan Kebahasaaraban 5, no. 1 (2018): 83-102. 
manfaat teknologi dalam pembelajaran bahasa Arab dari tingkat sekolah dasar hingga menengah atas. Dari manfaat tersebut, peneliti lebih menekankan pada stimulus, respon dan juga inovasi dalam pembelajaran berbasis pemanfaatan teknologi. Adapun penelitian yang dilakukan oleh Asiefatul Fikriyah lebih spesifik terhadap pemanfaatn aplikasi comic page creator. Sedangkan penelitian yang dilakukan oleh Abdul Rozak dan Azkia, mereka membahas desain perkuliahan bahassa Arab melalui media goggle classroom.

Sementara dalam kajian ini, peneliti membahas tentang apa bentuk media aplikasi dalam pembelajaran mahasiswa pascasarjana jurusan pendidikan bahasa Arab di UIN Maulana Malik Ibrahim Malang di tengah pandemi Covid-19 dan seberapa efektifitas media aplikasi tersebut dalam pembelajaran? Oleh sebab itu dapat disimpulkan bahwa penelitian tentang efektivitas aplikasi dalam pembelajaran mahasiswa pascasarjana jurusan pendidikan bahasa Arab UIN Maulana Malik Ibrahim Malang di tengah pandemi ini belum pernah dilakukan. Maka, dalam kajian ini, peneliti mengambil judul Efektifitas Media Online Dalam Pembelajaran Pada Masa Pandemi Covid-19.

\section{B. Metode Penelitian}

Pada kajian ini, peneliti menggunakan metode kualitatif.7 Adapun lokasi yang digunakan peneliti dalam kajian ini adalah Pascasarjana UIN Maulana Malik Ibrahim Malang dengan subjek penelitian mahasiswa pascasarjana jurusan PBA (Pendidikan Bahasa Arab) yang sedang menempuh semester II. Adapun metode yang digunakan peneliti dalam mengumpulkan data adalah teknik observasi, dokumentasi, wawancara dan mencatat. Demi mendapatkan data yang absah, peneliti menggunakan triangulasi sumber, data dan diskusi dengan teman sejawat. Triangulasi sumber, dilakukan dengan mewawancarai 10 mahasiswa, melalui teknik snowball dan purposive sampling. Untuk teknis analisis data, data-data yang

7 John W. Creswell, Research design pendekatan kualitatif, kuantitatif, dan mixed (Yogyakarta: ustaka Pelajar, 2010), hlm. 5. 
terkumpul pada penelitian ini akan dianalisis menggunakan analisis deskriptif dengan model analisis data Miles dan Huberman yaitu data reduction, data display, conclusion darwing/verification ${ }^{8}$

\section{Hasil dan Pembahasan}

Penelitian ini dilakukan terhadap beberapa mahasiswa pascasarjana jurusan Pendidikan Bahasa Arab (PBA) semester 2 UIN Maulana Malik Ibrahim Malang yang sedang menempuh pendidikan berbasis online pada semester genap tahun ajaran 2020/2021.

\section{Bentuk Media Aplikasi dalam Pembelajaran}

Sebelum mewabahnya Covid-19 kegiatan pembelajaran di pascasarjana UIN Maulana Malik Ibrahim Malang dilaksanakan secara tatap muka. Akan tetapi, setelah pandemi melanda, pembelajaran dilakukan secara online. Oleh karena itu, dalam menjalani perkuliahan berbasis daring ini, dosen serta mahasiswa harus memanfaatkan aplikasi yang dapat menunjang keberhasilan dalam perkuliahan yang akan berlangsung. Dari beberapa mahasiswa yang sedang menjalani pembelajaran di sekolah pascasarjana UIN Maulana Malik Ibrahim Malang secara online, mereka memanfaatkan beberapa aplikasi yaitu Zoom Meeting, Google Meet, E-Learning, dan Whatsapp Group.

Zoom Meeting merupakan aplikasi komunikasi dengan menggunakan video berbasis online. Aplikasi ini dapat digunakan di perangkat seluler, dekstop, dll. Pada umumnya aplikasi ini digunakan untuk meeting hingga konferensi video dan audio. Penggunaan Zoom Meeting dalam perkuliahan online sangat membantu karena pada aplikasi ini mendukung dalam menampilkan dokumen seperti power point, microsoft word, dll.

Selain Zoom Meeting, Google meet merupakan produk dari google yang merupakan layanan komunikasi video yang dikembangkan oleh google. Aplikasi

\footnotetext{
8 Sugiyono, Metode penelitian pendidikan:(pendekatan kuantitatif, kualitatif dan $R$ \& D) (Alfabeta, 2008), hlm. 337.
} 
ini juga berbasis online dan dapat digunakan melalui perangkat seluler, dekstop, dll. Sama halnya dengan zoom meeting, google meet pada umumnya juga digunakan untuk meeting. Dalam perkuliahan secara online, dengan google meet dosen dan mahasiswa dapat secara langsung bertatap muka. Dengan google meet juga dosen ataupun mahasiswa dapat menjelaskan dengan menampilkan materi yang sedang di sampaikan.

Selain aplikasi yang bisa dipakai untuk tatap muka secara online. Ada aplikasi lain yang digunakan tanpa harus adanya tatap muka yaitu E-learning. Elearning merupakan pembelajaran formal dan informal dengan menggunakan media elektronik. ${ }^{9}$ Pembelajaran menggunakan e-learning tidak mendukung terjadinya tatap muka ketika perkuliahan berlangsung. Di dalam E-learning dosen biasanya meng upload berbagai tugas untuk kemudian dikerjakan oleh mahasiswa, ataupun berdiskusi dengan mahasiswa. E-learning juga dimanfaatkan untuk pengisian presensi mahasiswa.

Selanjutnya aplikasi yang juga digunakan dalam pembelajaran secara online yaitu Whatsapp. Whatsapp merupakan salah satu aplikasi messenger yang paling banyak penggunanya untuk saat ini. ${ }^{10}$ Aplikasi whatsapp biasanya digunakan berbagai kalangan untuk bertukar pesan, melakukan obrolan online pada bagian video call, bertukar foto, berbagi dokumen, pesan suara, dan lain-lain.11 Penggunaan whatsapp dalam perkuliahan biasanya dilakukan oleh dosen dan mahasiswa untuk saling membagikan dokumen kemudian dilanjutkan dengan diskusi melalui pesan suara. Dalam perkuliahan fitur videocall juga dimanfaatkan untuk bertatap muka secara langsung via online.

Dari pemaparan di atas dapat diketahui bahwa dalam masa pandemi covid19, rata-rata dosen dan mahasiswa dalam melaksanakan proses perkuliahan

9 Lidia Simanihuruk dkk., E-Learning: Implementasi, Strategi dan Inovasinya (Yayasan Kita Menulis, 2019), hlm. 5.

10 Dayat Kurniawan, Membangun Aplikasi Elektronika dengan Raspberry Pi 2 dan Whatsapp (Jakarta: PT. Elex Media Komputindo, 2016).

11 Sitti Nurhalimah, Media Sosial dan Masyarakat Pesisir: Refleksi Pemikiran Mahasiswa Bidikmisi (Deepublish, 2019), hlm. 149. 
secara online memanfaatkan keempat aplikasi tersebut sebagai salah satu media pembelajaran.

\section{Efektifitas Media Aplikasi dalam Pembelajaran}

Pada masa pandemi ini, satu-satunya metode pembalajaran yang dapat digunakan oleh mahasiswa pascasarjana Pendidikan Bahasa Arab (PBA) UIN Maulana Malik Ibrahim Malang adalah pembelajaran berbasis online. Dalam penelitian yang telah dilakukan, ditemukan sebuah hasil penelitian, bahwasanya mahasiswa merasa lebih nyaman dalam mengemukakan pendapat dan pertanyaan ketika pembelajaran dilakukan secara online. Perkuliahan yang dilakukan dari rumah atau tempat dimana saja membuat mahasiswa tidak tertekan secara psikologis, baik dari dosen maupun teman kelas. Ketidakhadiran dosen secara langsung atau fisik menjadi sebab ketidakcanggungan mahasiswa dalam mengutarakan pendapat atau pertanyaan. Ketiadaan penghambat fisik, serta batasan ruang dan waktu juga menjadi sebab mahasiswa menjadi lebih nyaman dalam berkomunikasi. Jadi, pembelajaran secara online pada akhirnya membuat mahasiswa menjadi lebih berani dalam mengutarakan pendapat, sanggahan, pertanyaan, dan ide secara bebas.

Seperti yang temuan pada bagian sebelumnya, bahwa ada empat aplikasi yang digunakan dalam pembelajaran oleh mahasiswa pascasarjana jurusan PBA UIN Maulana Malik Ibrahim Malang yaitu;

\section{a. Zoom Meeting}

Pemanfaatan Zoom Meeting dalam kegiatan perkuliahan dinilai kurang efektif dikarenakan sering terjadi kendala pada sinyal atau jaringan internet bagi mahasiswa yang tidak menggunakan wifi yang nantinya akan berdampak terhadap kualitas pembelajaran yang diterima. Meski demikian, aplikasi ini dinilai praktis dan efisien bagi mahasiswa, karena komunikasi antar dosen dan mahasiswa lebih mudah dibandingkan berkomunikasi secara tertulis atau melalui chat. Gambar 1 menunjukkan aktivitas pembelajaran menggunakan Zoom Meeting. 


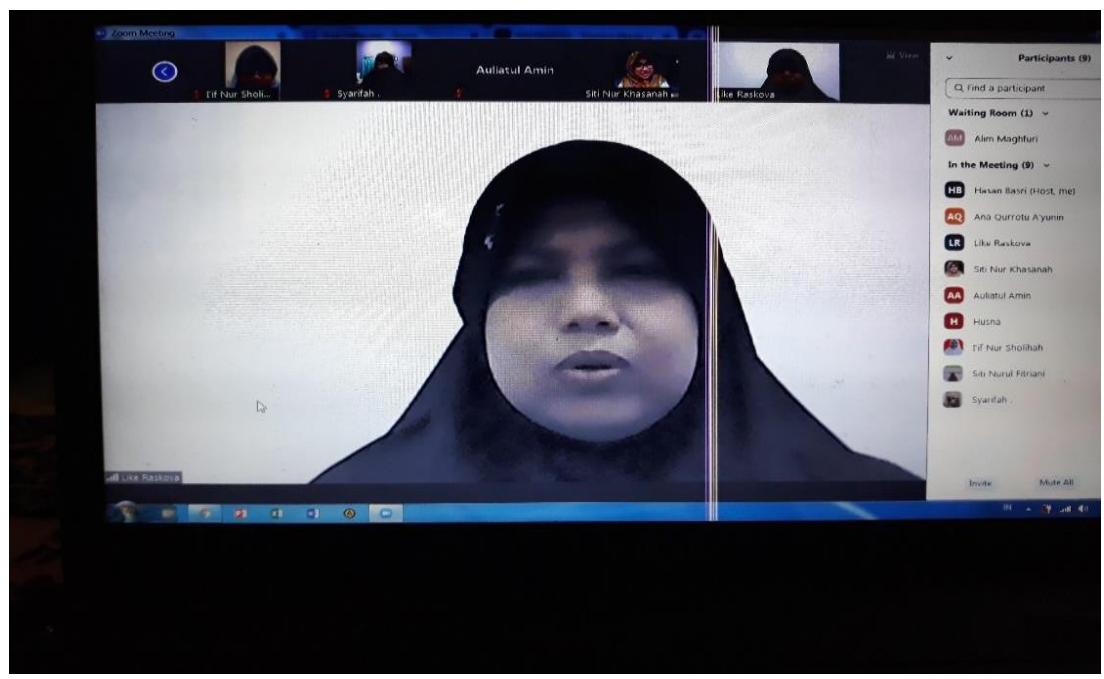

Gambar 1. Pembelajaran Online Menggunakan Zoom Meeting

b. Google Meet

Dalam pemanfaatan media aplikasi ini, adapun kekurangannya yaitu, membutuhkan jaringan internet yang stabil, dan adanya kendala ketika share screen. Sedangkan kelebihan dalam penggunaan google meet yaitu, lebih mudah diakses, kapasitas rendah, dan suara lebih jelas sehingga lebih efektif dan efisien. Gambar 2 menunjukkan tampilan penggunaan google meet dalam pembelajaran.

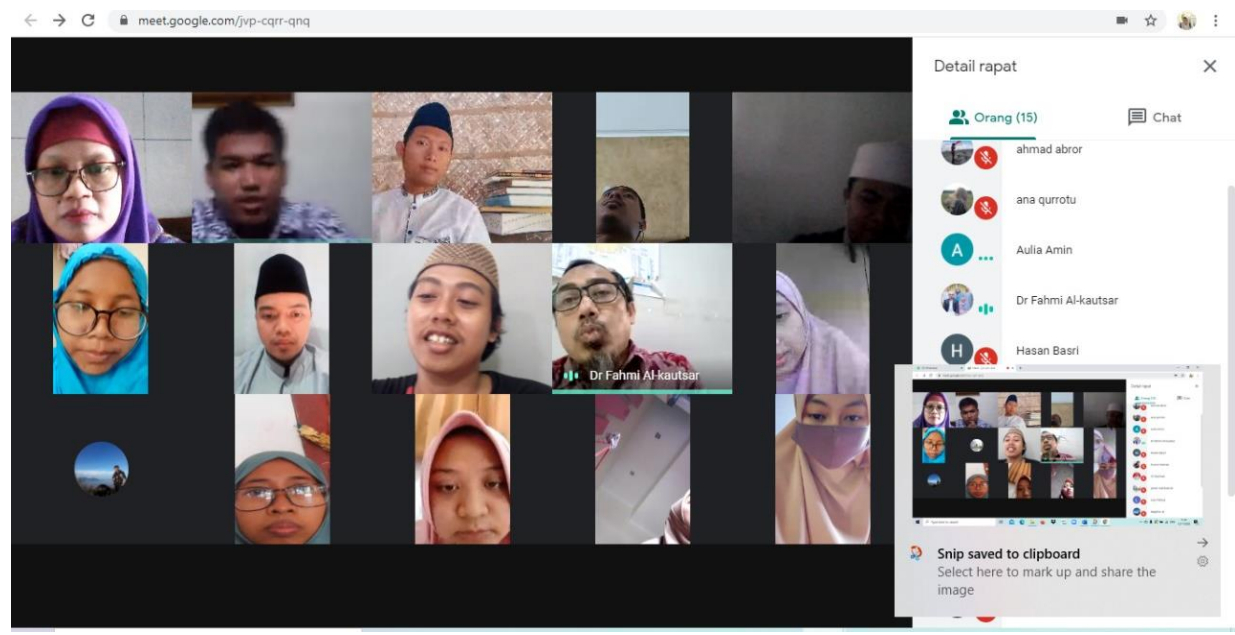

153 | Tarbiyatuna: Jurnal Pendidikan Ilmiah Vol. 5 No. 2 (Desember) 2020 
Gambar 2. Tampilan Perkuliahan dengan Media Google Meet

c. E-Learning

Terdapat kekurangan dan kelebihan yang disampaikan mahasiswa. Adapun kekurangan dalam pemanfaatan media aplikasi E-Learning dalam pembelajaran yaitu, kurangnya interaksi antara dosen dan mahasiswa, serta perubahan peran dosen dari yang semula menguasai teknik pembelajaran konvensional, kini dituntut untuk menguasai teknik pembelajaran dengan menggunakan ICT (Information Communication Tecnology), pembelajaran hanya bisa dilakukan dalam bentuk tertulis atau chat, adapun kelebihannya yaitu, memudahkan mahasiswa untuk absensi kehadiran, dosen dan mahasiwa dapat mereview materi maupun bahan ajar setiap saat dan dimana saja. Gambar 3 menunjukkan tampilan media e-learning dalam pembelajaran.

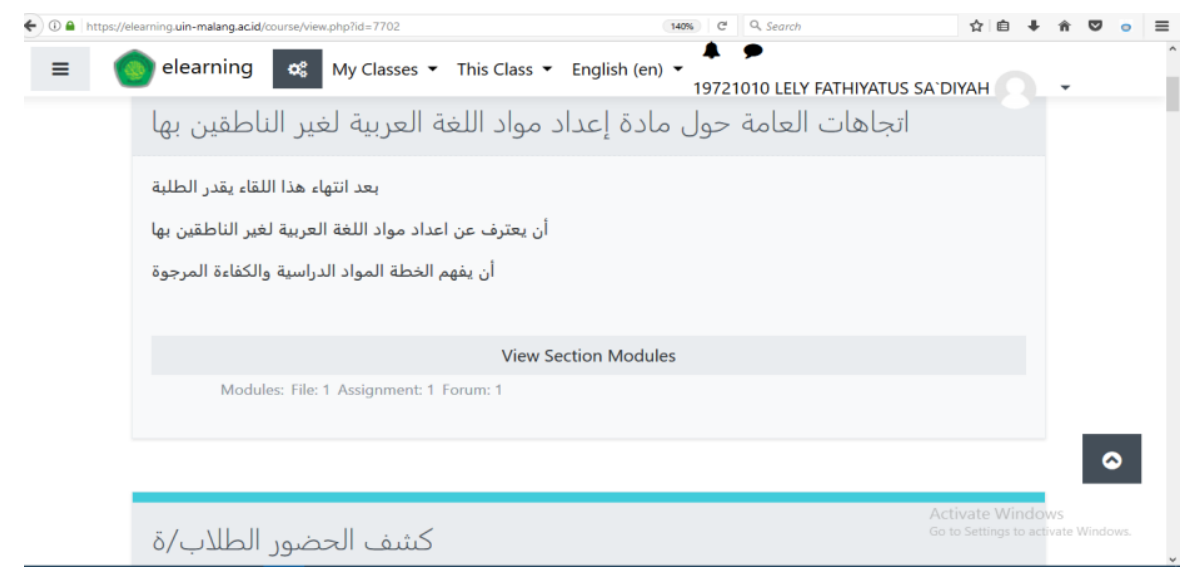

Gambar 3. Tampilan Penggunaan e-learning dalam Pembelajaran

\section{d. WhatsApp Group}

Dengan pemanfaatan media aplikasi WhatsApp Group ini, adapun kekurangan dalam sistem perkuliahan secara online yaitu, dosen memerlukan waktu persiapan dan penyiapan materi kuliah yang lebih banyak dibandingkan dengan kuliah secara luring, sedangkan kelebihannya yaitu dalam penyampaian materi perkuliahan menjadi lebih rapi, sistematis dan terstruktur. Di samping itu 
mahasiswa juga mempunyai waktu lebih untuk memahami paparan materi kuliah tanpa khawatir tertinggal karena mereka dapat membaca lagi materi yang telah disampaikan dosen dengan cara men-scroll ulang materi perkuliahan. Gambar 4 menunjukkan tampilan perkuliahan menggunakan whatsApp Group.

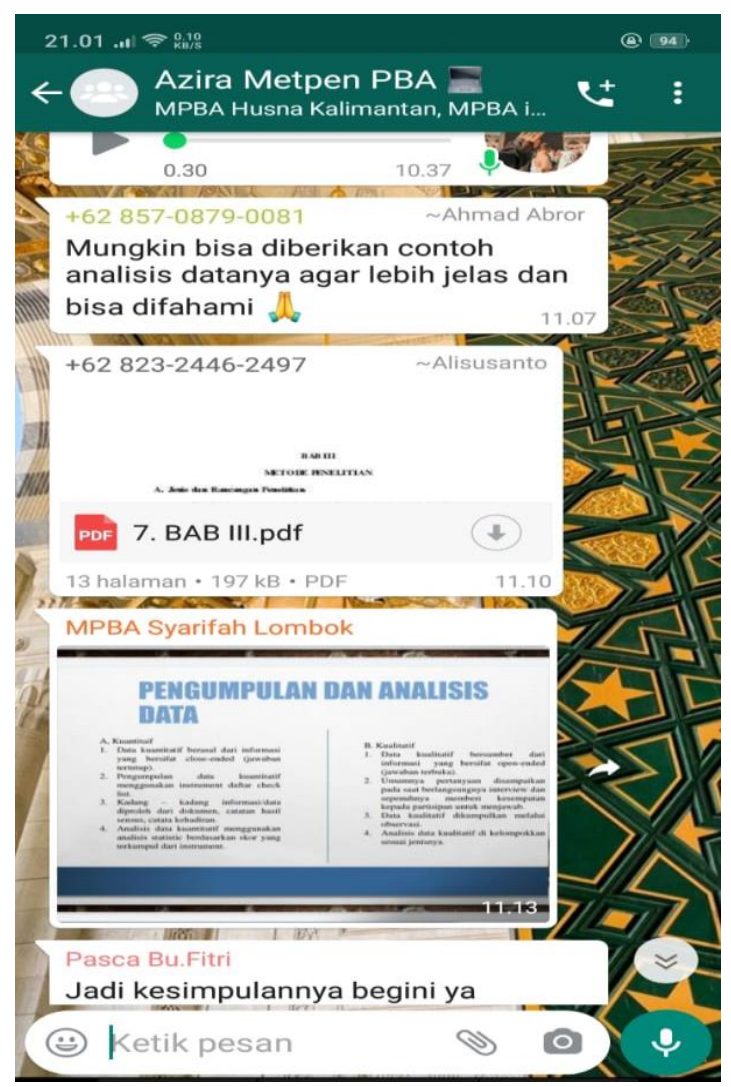

Gambar 4. Tampilan Perkuliahan menggunakan Media WhatsApp Group

Dari hasil-hasil penelitian yang diungkap, secara umum pembelajaran secara online dinilai memiliki sejumlah keterbatasan. Beberapa alasan yang dikemukakan: (1) seringnya terjadi kendala seperti signal atau jaringan internet yang kurang bagus, hal ini dikarenakan beberapa mahasiswa yang bertempat tinggal di daerah yang susah signal dan tidak menggunakan wifi. Pemadaman listrik juga menjadi kendala utama bagi mereka yang tinggal di daerah pedesaan, 
khususnya. Bahkan di beberapa daerah, ketika hujan tiba, akan mengalami pemadaman listrik. Hal ini dapat menganggu dalam pembelajaran, apalagi ketika tiba musim penghujan. (2) Sering terdengar suara disekitar sehingga mengganggu aktivitas pembelajaran online disaat sedang menyalakan voice.

Kesimpulan akhir, terdapat $70 \%$ mahasiswa yang merasa bahwa pembelajaran dengan memanfaatkan 4 media aplikasi (Zoom Meeting, Google Meet, E-Learning, dan Whatsapp Group) sudah efektif, karena dinilai praktis, serta dosen dan mahasiswa merasa lebih mudah melakukan komunikasi lisan dibandingkan tertulis. Dan dipilihnya ke empat media aplikasi tersebut sebagai salah satu media pembelajaran di pascasarjana Universitas Islam Negeri Maulana Malik Ibrahim Malang, dikarenakan untuk menghemat waktu dan biaya. Pemilihan media aplikasi online yang digunakan, yaitu didasarkan kesepakatan antara dosen dan mahasiwa, sehingga pembelajaran di pascasarjana jurusan PBA UIN Maulana Malik Ibrahim Malang sehingga bisa berlangsung secara efektif dan efisien.

\section{Kesimpulan}

Perubahan sistem perkuliahan pada masa pandemi covid-19, mengharuskan mahasiswa untuk kuliah berbasis online. Adapun beberapa pilihan media aplikasi yang digunakan yaitu Zoom Meeting, Google Meet, E-Learning, dan Whatsapp Group. Pemilihan dalam pemanfaatan aplikasi ini dilakukan melalui kesepakatan antara dosen dan mahasiswa, agar memudahkan dalam pembelajaran online.

Mayoritas mahasiswa menyatakan bahwa media-media aplikasi tersebut dianggap efektif, sebab dinilai praktis, menghemat biaya dan waktu, serta memudahkan komunikasi antara dosen dan mahasiswa kapanpun dan di manapun. Kendala yang sering menghambat efektivitas adalah masalah signal atau jaringan internet, terutama bagi mahasiswa yang tinggal di daerah yang susah signal dan tidak menggunakan wifi dan yang nantinya akan berdampak pula kepada kualitas pembelajaran yang mahasiswa terima. Temuan tersebut memberikan implikasi untuk tetap dipertimbangkannya pembelajaran secara 
online bila kondisi pandemi telah berlalu. Dapat dipadukan pembelajaran secara luring dan daring, dengan memanfaatkan media-media yang tepat.

\section{Daftar Rujukan}

Aji, Rizqon Halal Syah. "Dampak COVID-19 pada pendidikan di indonesia: Sekolah, keterampilan, dan proses pembelajaran." Salam: Jurnal Sosial dan Budaya Syar-i.(7) 5 (2020): 395-402.

Creswell, John W. Research design pendekatan kualitatif, kuantitatif, dan mixed. Yogyakarta: ustaka Pelajar, 2010.

Fikriyyah, Asiefatul. “Pemanfaatan Aplikasi 'Comic Page Creator' sebagai Strategi untuk Menggali Keterampilan Menulis dalam Bahasa Arab." Prosiding Konfererensi Nasional Bahasa Arab 3, no. 3 (2017): 282-88.

Iswanto, Rahmat. "Pembelajaran Bahasa Arab Dengan Pemanfaatan Teknologi." Arabiyatuna: Jurnal Bahasa Arab 1, no. 2 (2017): 139-52.

Kurniawan, Asep. "MANAJEMEN KERJASAMA LEMBAGA PENDIDIKAN ISLAM DENGAN MASYARAKAT (Studi Kasus Pondok Pesantren Alam Internasional Saung Balong al-Barokah Cisambeng Palasah Majalengka)." Holistik 15, no. 1 (2016).

Kurniawan, Dayat. Membangun Aplikasi Elektronika dengan Raspberry Pi 2 dan Whatsapp. Jakarta: PT. Elex Media Komputindo, 2016.

Leuwol, Natasya, dan Sherly Gaspersz. "Perubahan Karakter Belajar Mahasiswa Di Tengah Pandemik Covid-19." Civic-Culture: Jurnal Ilmu Pendidikan PKN dan Sosial Budaya 4, no. 1 Extra (2020): 32-44.

Nurhalimah, Sitti. Media Sosial dan Masyarakat Pesisir: Refleksi Pemikiran Mahasiswa Bidikmisi. Deepublish, 2019.

Rozak, Abd, dan Azkia Muharom Albantani. "Desain perkuliahan bahasa arab melalui google classroom." Arabiyat: Jurnal Pendidikan Bahasa Arab dan Kebahasaaraban 5, no. 1 (2018): 83-102.

Setiawan, Adib Rifqi, dan Arij Zulfi Mufassaroh. "Lembar Kegiatan Siswa untuk Pembelajaran Jarak Jauh Berdasarkan Literasi Saintifik pada Topik Penyakit Coronavirus 2019 (COVID-19)." Thesiscommons.org., 2020. 
Hasan Basri, Lely Fathiyatus Sa'diyah, Siti Nur Khasanah, Danial Hilmi

Simanihuruk, Lidia, Janner Simarmata, Acai Sudirman, M. Said Hasibuan, Meilani Safitri, Oris Krianto Sulaiman, Rahmi Ramadhani, dan Syafrida Hafni Sahir. E-Learning: Implementasi, Strategi dan Inovasinya. Yayasan Kita Menulis, 2019.

Sugiyono. Metode penelitian pendidikan:(pendekatan kuantitatif, kualitatif dan $R \&$ D). Alfabeta, 2008. 